BJHS 52(4): 543-567, December 2019. C British Society for the History of Science 2019. This is an Open Access article, distributed under the terms of the Creative Commons Attribution licence (http://creativecommons.org/licenses/by/4.0/), which permits unrestricted re-use, distribution, and reproduction in any medium, provided the original work is properly cited.

doi:10.1017/S0007087419000451 First published online 04 October 2019

\title{
'The want of a proper Gardiner': late Georgian Scottish botanic gardeners as intermediaries of medical and scientific knowledge
}

\author{
CLARE HICKMAN*
}

\begin{abstract}
Often overlooked by historians, specialist gardeners with an expert understanding of both native and exotic plant material were central to the teaching and research activities of university botanic gardens. In this article various interrelationships in the late Georgian period will be examined: between the gardener, the garden, the botanic collection, the medical school and ways of knowing. Foregrounding gardeners' narratives will shed light on the ways in which botanic material was gathered and utilized for teaching and research purposes, particularly for medical students, as well as highlighting the importance of the garden as a repository of botanic material for the classroom. In this way, the blurred lines between art and science, skill and scholarly activity, and shared pedagogic practices between botany and anatomy will be revealed.
\end{abstract}

\section{Introduction}

In 1754 William Cullen, at that time professor of medicine, and Robert Hamilton, Regius Professor of Botany and Anatomy, complained about the lack of a decent botanic garden at the University of Glasgow. Their proposal, which concerned the 'great garden', was to reconfigure it, making it 'more useful to the study of Botany'. ${ }^{1}$ At the same time, they stressed the need for 'getting a good gardiner'. ${ }^{2}$ The importance of a 'good' gardener was outlined in more detail in their memorial (a petition), directed to the honourable rector and other members of the University of Glasgow. As well as bemoaning the current state of decay of the fruit trees, the nature of the soil and its 'situation very much exposed to the smoke and the soot of the town', they argued that the university should 'take the proper measures for planting their Garden in a manner becoming a Society devoted to Taste and Science'. 3 They concluded by affirming that

* University of Newcastle, UK.

This research was conducted as part of a Wellcome Fellowship in History of Medicine and Humanities (WT 100388MA). I would particularly like to thank Charlotte Sleigh for her thoughtful editorial comments as well as the anonymous reviewers for their constructive and helpful feedback. Thanks also go to Tim Grady, Neil Pemberton, Kara Critchell and Tim Reinke-Williams for reading and commenting on earlier drafts of this work.

1 A.D. Boney, The Lost Gardens of Glasgow University, London: Christopher Helm, 1988, p. 88.

2 Boney op. cit. (1), p. 88 ..

3 Robert Hamilton and William Cullen, 'Memorial by Robert Hamilton, Professor of Anatomy and Botany, and Dr William Cullen, Professor of Medicine, to the University concerning the planting of more 
'on this occasion we cannot avoid observing that the study of Botany in this University has been very much retarded by the want of a proper Gardiner \& that the present appointments are insufficient for engaging one'. ${ }^{4}$ Nothing, however, came of the petition and Glasgow did not succeed in creating the type of botanic garden desired by Hamilton and Cullen until 1817 when the impetus was driven by Glaswegian citizens led by Thomas Hopkirk, with joint funding from the university, and subscribers of the Royal Botanic Institution of Glasgow. ${ }^{5}$

Nonetheless, the petition does highlight two interrelated issues that go to the heart of this article. First, it emphasizes the central role that good or 'proper gardeners' played in achieving a state-of-the-art garden in terms of planting and garden management. Second, it highlights the importance of a botanic garden that was simultaneously fashionable, ornamental and scientific in nature, thus revealing its dual purpose as both a teaching and civic space within the city. ${ }^{6}$

The eighteenth century can be seen as a transitional period in terms of both the design and use of university botanic gardens. This is best illustrated by turning to John Hope (professor of botany and materia medica and the King's Botanist) and his Edinburgh University garden, created in the 1760s on Leith Walk, which was well financed by Parliament. ${ }^{7}$ Hope's garden marked the change from the regular and formal design of traditional university physic gardens, with their central purpose as medicinal teaching spaces, to more picturesque and taxonomically arranged collections. This new type of garden further encompassed more economic and exotic botanic specimens as they arrived in Britain from around the globe. With its growing collection obtained from exploratory voyages, the garden also attracted a broader range of visitors and users, from the serious student to the merely curious. Indeed, in 1782 Hope even had to introduce a ticketing system to regulate visitors, due in part to the fashionable interest in botany in this period. The Caledonian Mercury recorded that by this regulation it is not meant to render access to the Garden difficult. Strangers, the Gentlemen of this county, the citizens of Edinburgh, and any person of knowledge or curiosity upon sending their names ... will receive an order for seeing the Garden'. ${ }^{8}$

This desire to entertain and inform the curious as well as the knowledgeable had an impact on the layout as well as the content of the botanic collections. ${ }^{9}$ This is evident in Elliot, Watkins and Daniels's work on public and semi-public arboretums

trees and shrubs in the College garden in place of the decayed fruit trees', Glasgow University Archives, GUA 5412 .

4 Hamilton and Cullen, op. cit. (3).

5 Historic Environment Scotland, inventory of gardens and designed landscapes, Glasgow Botanic Gardens, GDL00190, 1987.

6 The relationship between the city and the Georgian botanic garden has been expertly outlined by Paul Elliott in Enlightenment, Modernity and Science: Geographies of Scientific Culture and Improvement in Georgian England, London and New York: I.B. Tauris, 2010.

7 Henry Noltie, John Hope (1725-1786), Edinburgh: Royal Botanic Garden Edinburgh, 2011, p. 19.

8 'Botanic Garden', Caledonian Mercury, 4 May 1782, p. 1.

9 Clare Hickman, 'Curiosity and instruction: British and Irish botanic gardens and their audiences, 1760-1800', Environment and History (2018) 24(1), pp. 59-80. 
(taxonomically organized collections of trees) in the nineteenth century. They examine how financial concerns forced botanical societies to attract subscribers and paying visitors. As a result, 'there was pressure to apply the principles and practices of landscape gardening to create visually attractive spaces'. ${ }^{10}$ This tension emerges in the late eighteenth century as aesthetic landscape principles were implemented in botanic gardens to attract casual visitors and subscribers, sometimes to the obfuscation of the scientific and medical roles of the botanic garden. Johnson describes how at Glasnevin, Dublin, the garden became 'a contested space, where the divergent views of the expert and amateur made their presence felt'. ${ }^{11}$ Similarly at Oxford, John Sibthorp, as Sherardian Professor of Botany, argued that despite their inferiority of 'Magnificence and Splendour' compared to those given royal financial backing, academic botanic gardens were more useful as 'their Object [was] to inform as well as amuse'. ${ }^{12} \mathrm{He}$ went on to state that 'Picturesque Beauty is not merely considered, but method \& order as far as they conduct to a systematic arrangement must be preserved'. ${ }^{13}$ This delineates the connections between finance and botanic collections, which will be explored in more detail later, as well as the distinction Sibthorp perceived between the picturesque on the one hand and method and order on the other. This relationship between science and aesthetics builds particularly upon the work of Nuala Johnson, who has expertly discussed these connections in relation to the botanic gardens of Cambridge, Belfast and Dublin, particularly during the nineteenth century. ${ }^{14}$

The real significance of the 1777 plan of John Hope's Leith Walk garden (Figure 1) in Edinburgh lay, then, in its attempt to combine scholarly order with picturesque beauty rather than to draw a line between the two. This in turn expanded the role of the gardener. In this new garden the traditional formal beds growing medicinal plants, which were central to earlier physic garden design, were moved to one side. Instead the main body of the garden was laid out with shrubs, flowers and trees according to both taxonomic order, particularly the Linnaean system, and the picturesque design principles of the day, which were implemented in the serpentine paths winding between beds. ${ }^{15}$ At the centre of this landscape, combining 'order and beauty', was the large glasshouse with its exotic specimens, whilst just outside the walls there was an experimental field growing the economically valuable crop of rhubarb. ${ }^{16}$

10 Paul Elliott, Charles Watkins and Stephen Daniels, “Combining science with recreation and pleasure”: cultural geographies of nineteenth-century arboretums', Garden History (2007) 35(2), pp. 6-27, 15.

11 Nuala Johnson, 'Grand design(er)s: David Moore, natural theology and the Royal Botanic gardens in Glasnevin, Dublin, 1838-1879', Cultural Geographies (2007) 14(1), pp. 29-55, 38.

12 Lecture Four from a course of thirty lectures on botany by John Sibthorp, Sherardian Library, University of Oxford, MS Sherard 219, p. 67.

13 Sibthorp, op. cit. (12) p. 67.

14 Nuala Johnson, Nature Displaced, Nature Displayed: Order and Beauty in Botanical Gardens, London: I.B. Tauris, 2011.

15 For more detail on the design of Hope's garden see Johanna Lausen-Higgins, 'Sylva botanica: evaluation of the lost eighteenth-century Leith Walk Botanic Garden Edinburgh', Garden History (2015) 43(2), pp. $218-236$.

16 For an expert reading on design and the transition to nineteenth-century botanic gardens see Johnson, op. cit. (14). 


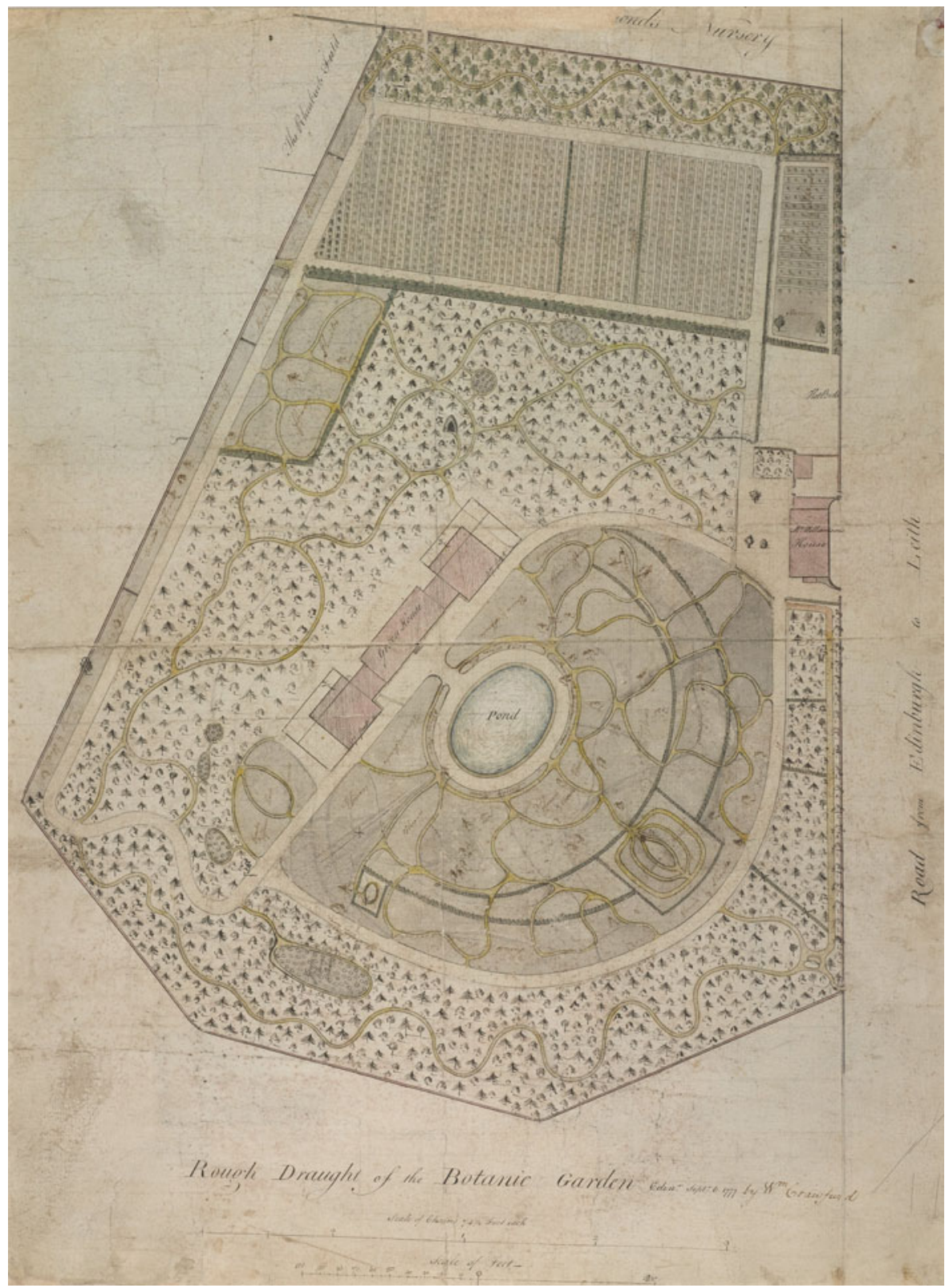

Figure 1. Plan of the Leith Walk garden, 1777, showing the regimented lines of the Schola Botanica or physic garden at the top of the image, the glasshouse in red at the centre and the botanic cottage in red on the right of the image by the perimeter wall. Royal Botanic Garden Edinburgh Archive, A77 ret. Reproduced with permission from the Royal Botanic Garden Edinburgh. 
This physical manifestation, displaying both formal and picturesque elements, was complemented with a transition in pedagogical methods from teaching botany through multi-sensory engagement to an approach that favoured the visual over the other senses. In his lectures Hope argued that the most important senses for students to develop were taste and smell. Yet it is clear that in his teaching he also utilized visual methods, such as specially commissioned large teaching diagrams, the demonstration of plant experiments, and the facilitation of close observation of plant dissections. Individual students conducted these dissections using specimens provided by the gardener.

Margaret Maria Olszewski has expertly discussed this move towards the preference of the visual in botanic teaching in reference to the introduction of botanical models in the mid-nineteenth century. As well as making teaching more engaging and easier for large groups of students, she argues that there were also financial savings. As the professor 'would have been responsible for paying assistants' wages, a collection of easy-to-use materials that required no assistants ... was an economically sound investment'. ${ }^{17}$ Olszewski also notes that there would have been savings in not having to gather specimens from the garden on an almost daily basis for teaching purposes. Again, economic concerns are important factors to consider and one of the reasons Hope was able to create such an expensive teaching resource was his ability to gain extra financing from government for his enterprise. ${ }^{18}$ This in turn allowed him to maintain a large staff of gardeners who could facilitate the multi-sensory pedagogical approach to botanic teaching that he favoured. As Noltie notes, Hope's large collection of teaching drawings indicate a belief in the value of visual material even though this is not explicitly recorded in his lecture notes. Instead they seem to have been employed alongside, rather than eclipsing, education through the other senses. ${ }^{19}$

The interrelationship between the gardener and the physical space and its activities can be seen in this letter from Thomas Martyn, professor of botany at the Cambridge Botanic Garden in the 1760s. At Martyn's garden, the lack of finances was a key limitation:

I have almost ended my Course of Lectures for this year. My pupils are but few in number; and there are fewer still who give any attention to the science. I hope, however, by perseverance, to bring it more into repute among us. The Garden gets on very well in point of plants, under the direction of Mr. Miller; but our income is still very scanty, so that we cannot finish our Greenhouse, much less build stoves: indeed, we are obliged to use a degree of frugality not very consistent with the dignity of an University, or the usefulness of the design; but we keep it on foot for better times!20

Without the necessary technology of glass and heating, there were limitations to what plants the gardener could grow, which in turn limited the specimens available for

17 Margaret Maria Olszewski, 'Dr. Auzoux's botanical teaching models and medical education at the universities of Glasgow and Aberdeen', Studies in History and Philosophy of Biological and Biomedical Sciences (2011) 42(3), pp. 285-296, 288.

18 One of John Hope's most influential patrons was Lord Bute, and Hope took advantage of Bute's short time as prime minister (1762-1763) to successfully request funds from the Lords of the Treasury for the garden. See Noltie, op. cit. (7), p. 19.

19 Noltie, op. cit. (7), p. 80.

20 Letter from Thomas Martyn to Dr Pulteney, 31 May 1766, in George Cornelius Gorham, Memoirs of John Martyn and of Thomas Martyn, London: Gaulter Printer, 1830, p. 132. 
teaching from the garden itself. This was particularly crucial when learning taxonomy, which required the study of many different species of plants at first hand. Such limited teaching space was likely to attract fewer students and, as fees were paid directly to each lecturer rather than via the university, this in turn affected the funds available for the garden and its gardeners. Martyn tried various methods to keep his teaching going in Cambridge. One such innovation was to transform his original botanic lecture series into a general natural-history course, including animals and fossils, before abandoning lecturing altogether in 1796 due to lack of interest from students. ${ }^{21}$

As this article will explore, one of the clear roles of the head gardener, or custodian, as he was termed at Oxford, was as the provider of large quantities of botanic specimens for the classroom. This was in part a response to a fascination with taxonomic systems, such as that promoted by Linnaeus, which required close examination of the plant's sexual organs. Hope, along with Thomas Martyn, was one of the first to teach this system. ${ }^{22}$ It is clear from notes recording Hope's lectures that close examination through dissection formed a central part of his teaching method. In reference to a dissection of a tulip, he explained that it is necessary to be neat and cautious in your dissections \& repeat them often'. ${ }^{23}$

The case studies of William Lang, a gardener at Glasgow, and of John Williamson and Andrew Fyfe at Edinburgh, allow us to interrogate how gardeners were instrumental in facilitating this pedagogical approach, through the maintenance and use of collections of vast quantities of living specimens. As Johnson has noted in her work, particularly in relation to David Moore (curator of the Glasnevin botanic gardens in mid-nineteenthcentury Dublin), such men often occupied a hybrid position between gardening and science'. ${ }^{24}$ These three cases further highlight the interrelationship between the gardener, the garden as a physical entity and the gardener's role as intermediary between the collection and other human actors. As well as encouraging us to see science as geographically grounded, historical geographers such as David Livingstone have highlighted how 'spaces are produced, made, constituted by human actors', which emphasizes the importance of the role of people, including technicians and labourers such as gardeners, in the creation and use of scientific spaces. ${ }^{25}$ Emma Spary has expertly explored the relationship between the network of human actors and the botanic garden with particular attention to the Jardin du roi, Paris. Through this work she has established that there was a network of many different participants of differing levels of skill, including day labourers and expert botanic gardeners, who were all needed to maintain, understand and share

21 'When he had read Lectures in the science, which was his favourite study, for a few years, he found it necessary to add the other branches of Natural History, Animals, and Fossils; Botany not being then sufficiently popular to keep together a class on that single subject!' In Gorham, op. cit. (20), pp. 127-128.

22 Gorham, op. cit. (20), p. 118.

23 Anon., 'Lectures on Botany by John Hope MD in the Royal Botanick Garden Edin.. 1777-8', Royal Botanic Gardens Archives (hereafter RBGE), p. 168.

24 Johnson, op. cit. (11), p. 45.

25 David Livingstone, 'Keeping knowledge in site', History of Education (2010) 39(6), pp. 779-785, 782. See also David Livingstone and Charles Withers (eds.), Geographies of Nineteenth-Century Science, Chicago: The University of Chicago Press, 2011. 
knowledge regarding the living collections. ${ }^{26}$ As these geographers and historians suggest, scientific knowledge creation in the botanic garden can best be viewed as cocreated between the gardeners and the spaces they shaped and inhabited.

Gardeners, then, can be seen as particularly vital actors in this period, as they created and maintained the physical space and its living specimens, as well as functioning as intermediaries between different audiences, and between humans and plants. The consideration of this interrelationship between actors, objects and methods of enquiry builds on that explored by scholars included in Klein and Spary's Materials and Expertise in Early Modern Europe: Between Market and Laboratory. ${ }^{27}$ Gardeners, in addition, offer a new way to consider the relationship between practical and scholarly work as already explored by a range of authors in work such as The Mindful Hand. ${ }^{28}$ This article examines the blurring of demarcations between the head and the hand within the botanic garden through the various roles of the gardeners as toilers of the soil, collectors of specimens, custodians of collections, demonstrators, guides, artists and experimental technicians. As they created the space in which they worked, as well as facilitating research and pedagogical activities, gardeners are particularly useful objects of study, as they challenge distinctions between skill, craft and scientific endeavour. Gardeners, therefore, provide a way to consider the connectedness between art and science as methods of knowing, methods that characterize not only botany but also anatomy.

\section{The garden as a botanical classroom}

Botanic courses in this period were generally open to anyone who paid the fee, but the main audience was medical students. In Edinburgh, botany was a compulsory subject from 1777 along with anatomy and surgery, chemistry, materia medica and pharmacy, medical theory and practice, and the clinical lectures of the Royal Infirmary. ${ }^{29}$ This is not to say that all medical students attended botanical lectures. As Lisa Rosner has identified, in Edinburgh 'it only attracted an average of 25 percent of students in each cohort' ${ }^{30}$ This was partly because the course ran in the summer months when students wanted to be back home but it was also not the most sought-after skill. According to the Guide for Gentlemen Studying Medicine at the University of Edinburgh, as noted by Rosner, the main reason for studying botany was that 'it would keep the practitioner's abilities from "being called into question by his ignorance of the principles of a science which is vulgarly believed to be necessary"'. ${ }^{31}$ As with all student feedback, this is only

26 Emma Spary, Utopia's Garden: French Natural History from Old Regime to Revolution, Chicago: The University of Chicago Press, 2000.

27 Ursula Klein and Emma Spary (eds.), Materials and Expertise in Early Modern Europe: Between Market and Laboratory, Chicago: The University of Chicago Press, 2010.

28 Lissa Louise Roberts, Simon Schaffer and Peter Robert Dear (eds.), The Mindful Hand: Inquiry and Invention from the Late Renaissance to Early Industrialisation, Amsterdam: Koninkliijke Nederlandse Akademie van Wetenschappen, 2007.

29 Lisa Rosner, Medical Education in the Age of Improvement: Edinburgh Students and Apprentices, 1760 1826, Edinburgh: Edinburgh University Press, 1991, p. 63.

30 Rosner, op. cit. (29), p. 56.

31 Rosner, op. cit. (29), p. 57. 
one opinion and it is clear that John Hope's lectures on botany at Edinburgh were well attended. The range of students attending went well beyond those with medical interests, suggesting a shift away from medicinal botany to botanical study in its own right, as well as a growing interest in botany for agricultural and other economic purposes.

As well as highlighting the problems of funding these complex spaces, Cambridge offers an insight into this eighteenth-century transition between the earlier physic garden and the nineteenth-century scientific botanic garden. In 1725 Richard Bradley, the first professor of botany at Cambridge, declared that for real improvements to be made in British agriculture farmers required 'opportunities and judgement to try experiments' or 'some fixed place, where they might see examples of all kinds of husbandry'. ${ }^{32}$ He hoped that as well as collecting plants for medicinal use and 'choice vegetables from foreign countries', the Cambridge garden would make a little space available 'for experiments tending to the improvement of land, which may be the means of increasing the estate of every man in England'. ${ }^{33}$ The long-awaited Cambridge botanic garden was eventually created in 1760 through the benefaction of Richard Walker. However, in many ways it represented a step backwards as it mirrored the design and uses of traditional physic gardens (it was based on the Chelsea Physic Garden), with their focus on medicinal plants and associated benefits for human health. Walker stated that 'the knowledge of plants is also of the greatest Utility to Mankind, as the practice of Physic is principally founded thereon' ${ }^{34}$ Johnson notes, the resultant garden was designed to advance the medical uses of botany and the small size of the plot meant that larger plants such as trees were for the most part excluded. However, Thomas Martyn did adopt the teaching of Linnaean principles at the same time as Hope, and the garden was laid out with these in mind. This resulted in a more rigid garden plan, designed with taxonomy and medicine in mind, but with less room for the experimental, economic and agricultural botany as advocated by Bradley and implemented by Hope.

This emphasis on agriculture and economy is key to understanding the design and use of later botanic gardens. Unlike Oxford and Cambridge, where medical teaching was perhaps stagnating at this point, in Edinburgh and Glasgow the subject was flourishing. In the case of Edinburgh, botanic teaching was at the cutting edge, incorporating experimental modes of demonstration, plant physiology and Linnaean taxonomy, all the while responding also to wider concerns regarding agricultural improvement. Scotland, as Stephen Shapin has highlighted, was home to a large public audience interested in science and the "improvement" of the Scottish nation, most importantly via the modernization of agricultural techniques and production'. Much of this activity was centred on the Edinburgh medical school. ${ }^{35}$ Both Paul Wood and Charles Withers have investigated

32 Richard Bradley, 'Preface', in Bradley, A survey of the ancient husbandry and gardening, London: Printed for B. Motte, 1725, n.p.

33 Bradley, op. cit. (32).

34 Bradley, op. cit. (32). For more on this see Johnson, op. cit. (14), p. 20; and Nuala Johnson, 'Cultivating science and planting beauty: the spaces of display in Cambridge's botanic gardens', Interdisciplinary Science Reviews (2006) 31(1), pp. 42-57.

35 Steven Shapin, 'The audience for science in eighteenth-century Edinburgh', History of Science (1974) 12 (2), pp. 95-121, 97. 
the offering of public and private lectures on agricultural topics, which were common throughout the period, and identified this with a particularly Scottish context. ${ }^{36}$

Scotland was also important as a breeding ground for gardeners. As Ron McEwan notes,

Sir Joseph Banks ... described Scotland as a 'nation of gardeners' ... and favoured them as plant collectors because he said, 'so well does the serious mind of a Scotch education fit Scots men to the habits of industry, attention and frugality that they rarely abandon them at any time of life'. ${ }^{37}$

This, combined with relatively high literacy rates, meant that Scottish gardeners were sought after and the Scottish botanic gardens, particularly Hope's Leith Walk garden, can be seen as a training ground for future leading plant collectors, nurserymen and head gardeners. ${ }^{38}$ This is evident when tracing the biographies of those working in botanic gardens in the nineteenth century; curators at institutions such as the Belfast and Dublin botanic gardens were Scottish, and trained in Scotland. ${ }^{39}$

In Scotland there was also an added emphasis on the relationship between improvement through the study of natural knowledge and the construction of the 'polite' gentleman who was expected to understand natural phenomena. ${ }^{40}$ Developing this geographical connection further in relation to discourses of improvement, Fredrik Albritton Jonsson argues that the push for improvement in Scotland in particular was often based on a goal of national self-sufficiency. ${ }^{41}$ As Hope was one of the intellectuals interested in this movement it was perhaps not surprising that his Leith Walk botanic garden should have included space for trees, which had economic value, and for other potentially lucrative plants, such as rhubarb. ${ }^{42}$

The inclusion of larger trees and shrubs also encouraged more picturesque planting with sinuous paths that allowed larger individual specimens to grow in their natural shape, both for classification purposes (essential for the 'natural' system) and to be shown off to

36 Paul Wood, 'Candide in Caledonia: the culture of science in the Scottish universities, 1690-1805', in M. Feingold and V. Navarro-Brotons (eds.), Universities and Science in the Early Modern Period, Dordrecht: Springer, 2006, pp. 183-199; Charles Withers, 'William Cullen's agricultural lectures and writings and the development of agricultural science in eighteenth-century Scotland', Agricultural History Review (1989) 37(2), pp. 144-156.

37 Ron McEwan, 'The northern lads: the migration of Scottish gardeners with especial reference to the Royal Botanic Gardens, Kew', Sibbaldia (2013) 11, pp. 109-123.

38 The migration of Scottish gardeners to England had been condemned as early as 1718 by Stephen Switzer, who complained that 'there are likewise several Northern Lads, which whether they have served any time in this Art, or not, very few of us know anything of; yet by the help of a little Learning and a great deal of Impudence, they invade these Southern Provinces'. Stephen Switzer, Ichnographia rustica; Or, The nobleman, gentleman, and gardener's recreation, vol. 1, London: D. Browne, 1718, Preface, p. xxiv. For more on the Scottish network of gardeners see Sue Shephard, Seeds of Fortune: A Gardening Dynasty, London: Bloomsbury, p. 200. See McEwan, op. cit. (37), for more on the important role of Scottish gardeners, and Kew and Noltie, op. cit. (7), on the role of Leith Walk in training gardeners and plant collectors.

39 See Johnson, op. cit. (11), p. 125; and Johnson, op. cit. (14), p. 77.

40 Wood, op. cit. (36), pp. 183-199.

41 Fredrik Albritton Jonsson, 'Scottish tobacco and rhubarb: the natural order of civil cameralism in the Scottish Enlightenment', Eighteenth-Century Studies (2016) 49(2), pp. 129-47.

42 See Jonsson, op. cit. (41), for a detailed analysis of this. 
visitors. ${ }^{43}$ This again reflects a movement towards a new taxonomic aesthetic that included trees as well as the traditional smaller plants found in earlier physic gardens. Although Hope did not delineate an area specifically as an arboretum within the Leith garden, there were enough trees within the garden for the landscape designer John Claudius Loudon to note an area with this term on his own copy of the Leith Walk plan. ${ }^{44}$ By the mid-nineteenth century, taxonomically organized tree collections had become an important feature of the botanic landscape; the Leith Walk garden was on the cusp of this shift. ${ }^{45}$

Back in Cambridge there was far less irregularity in the design of the garden, and the resultant rigidity was also reflected in the demarcation of roles within the garden that Walker stipulated. A 'Reader on Plants', as the academic role was described, was to be 'proficient in Botany, and otherwise qualified in learning, so as to read his lectures in Latin or English'. Whereas the horticultural curator 'should always be so well skilled in the System of Botany so as to range his Plants in their proper order'. ${ }^{46}$ However, this distinction became blurred when the first curator, James Miller (son of Philip Miller the head gardener of Chelsea Physic Garden), quit after seven years, leaving Martyn to take up the role of both curator and reader. This highlights the close relationship between the applied and theoretical work of the garden; these posts could be interchangeable as well as interrelated.

This close relationship played out a different way in Oxford, where James Benwell worked for more than forty years as a gardener. His exact position is unknown but presumably he worked under the head gardener or custodian of the garden whilst Sibthorp was the professor. Despite his lack of distinction, he was remembered by the botanist and later custodian of the garden William Baxter as 'although uneducated, a very intelligent man'. ${ }^{47}$ Baxter went on to note that Benwell had an 'accurate knowledge of British Plants, and of their localities in the vicinity of Oxford, and a singular talent for observation in every branch of Natural History'. ${ }^{48}$ Benwell's practical understanding of botany rendered his services highly valuable, in Baxter's opinion. In particular, Benwell assisted Sibthorp in his herborizations (the collection of botanic specimens in the field) when he was working on his Flora Oxoniensis. Thus we have a member of the garden network whose role extended beyond the garden and who was credited with expert knowledge despite being employed in a role below that of head gardener. Indeed, on his retirement at the age of eighty-two, a portrait depicting him returning from a botanical expedition to the field, with the Danby Arch of the Oxford botanic garden in the background, was engraved to raise money to support him in his final years (Figure 2). ${ }^{49}$

43 Beryl Hartley, 'Sites of knowledge and instruction: arboretums and the Arboretum et Futicetum Britannicum', Garden History (2007) 35(2), pp. 28-52, 30.

44 Hartley, op. cit. (43). The term 'arboretum' was probably first used by Loudon in 1806, according to Hartley.

45 See Elliott, Watkins and Daniels, op. cit. (10).

46 Thomas Martyn, A short account of the late donation of a botanic garden to the University of Cambridge by the Reverend Dr. Walker ..., Cambridge: Printed by J. Bentham, 1763, p. 5.

47 William Baxter, British phaenogamous botany; Or, Figures and descriptions of the genera of British flowering plants, vol. 6, Oxford: Published by the author, 1834, p. 419a.

48 Baxter, op. cit. (47), p. 419a.

49 Details of this and a brief sketch of his life can be found in a letter from the apothecary John Ireland to the Oxford Journal, Saturday 29 November 1817. 


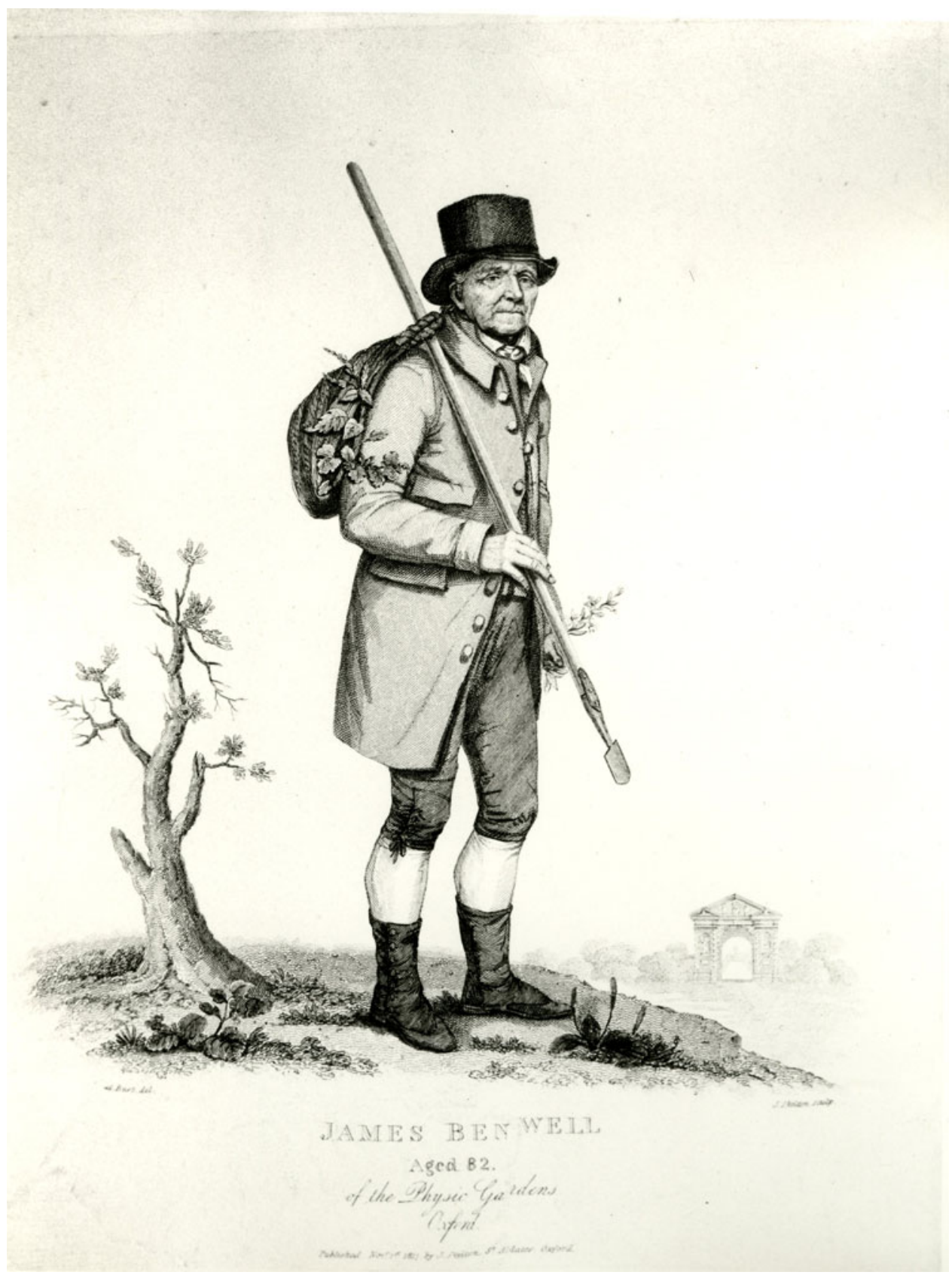

Figure 2. Engraving of gardener James Benwell, on his retirement from the University of Oxford Botanic Garden. It depicts him returning from a plant collecting trip (or herborization) with the entrance arch to the botanic garden in the background. By Joseph Skelton after A. Burt, 1817. Reproduced with permission from the Oxford University Herbaria, Department of Plant Sciences. 
We have limited biographical details of gardeners such as Miller and Benwell; they are indeed barely visible within the archives. In contrast, we have a personal record of tasks undertaken by William Lang, a botanic gardener in Glasgow, as well as the detailed notes and accounts kept by Hope regarding his practice at Edinburgh. Through these, we can see the essential nature of gardeners as skilled intermediaries operating within teaching and experimental botany.

\section{'Because a certain number of different plants, all in flower, must be had for each lecture': William Lang and the Glasgow University gardens}

It is rare to find accounts written first-hand by botanic gardeners in the late Georgian period, so it is worth beginning at Glasgow with the personal experience of William Lang, who was forced to defend his reputation as a good gardener in the 1800s. Lang probably learnt his trade from his father, Robert Lang, who had been appointed to the post of college gardiner in 1784. Robert's job description was 'to take care of the Physick Garden and to keep in order the College Garden by cutting walks and rolling them, clipping the Hedges, dressing the borders etc'. ${ }^{50}$ William probably conducted similar work to his father, at least initially. ${ }^{51}$

The wages for such work were rather paltry, with Robert Lang being given 'a salary of Ten pounds a year ... and ... a house rent-free. The said Gardiner is also to have the grass of the College Garden for which he is to pay Ten pounds as yearly rent'. ${ }^{52}$ As Boney suggests, it would seem that profit from sales of the grass, most likely as a crop of hay, was the only real income for the gardener and his family, although this was both weatherand market-dependent. The lack of proper pay was an ongoing issue. In 1789, William Hamilton, in his role as professor of anatomy and botany, managed to argue that there was enough work in the various gardens to pay Robert seventeen pounds a year, along with the grass of the college garden (estimated at eight pounds sterling), and one pound for tools. ${ }^{53}$ The downside to this was that 'no wages will be paid to him for labourers or to other assistants employed by him unless he produce a written order from the Garden Committee for employing them'. ${ }^{54}$ Given that there was an awareness of how important a specialist gardener was to the provision of botanical teaching, as laid out in Cullen and Hamilton's earlier petition, he was obviously still viewed by much of the faculty as any other labourer. He was responsible for the various gardens on his own - although at least the committee considered the role to be a full-time one for the first time. ${ }^{55}$

50 Boney, op. cit. (1), p. 187.

51 From the detailed and expert research conducted by Arthur Boney, Robert seems to have undertaken much of this work himself with the aid of paid day labourers (and presumably also his son, who succeeded him in the role in 1801).

52 Boney, op. cit. (1), p. 192.

53 Boney, op. cit. (1), p. 192.

54 Boney, op. cit. (1), p. 192.

55 We can compare this with Lee and Kennedy's nursery in Kensington in the 1820s, which is recorded in a letter by Dr Schultes in W.J. Hooker's Botanical Miscellany: Containing Figures and Descriptions of Such Plants as Recommend Themselves by Their Novelty, Rarity or History, or by The Uses To Which they are 
When William Lang took over from his father in 1801, the terms of his employment remained much the same. However, the difficulties he began to face seem to be related directly to the development of botanical teaching at Glasgow and the increasing numbers of students. Towards the end of Lang's father's tenure in 1798, student numbers had gradually decreased to a low point of eight under Professor James Jeffray's tutelage. ${ }^{56}$ The student figures recovered back to twenty-two in 1801 under Dr Thomas Brown, who was appointed by Jeffray to cover his botanical teaching. After this time the student numbers then rose steadily, reaching fifty-five by $1810 .{ }^{57} \mathrm{It}$ was this rise in the number of students attending the course that appears to have caused cracks to emerge in Lang's ability to fulfil his role.

In 1806, Brown, as the botany lecturer, wrote to Jeffray in response to criticism regarding the management of the physic garden:

I am very sorry to learn that the College is dissatisfied with William Lang's behaviour \& I am much afraid that it has been improper in many respects, but I can only say that as far as the Botanical Department is concerned I have no fault to find, but every reason to be completely pleased with it. That plot of ground which is dignified with the name of Botanic Garden is so very barren, that its produce can scarcely be of any advantage to a lecturer of Botany. He is therefore, under the necessity, during the greatest part of the course, both of collecting plants himself in the fields $\&$ in neighbouring gardens, $\&$ of trusting to the exertions of the gardener. ${ }^{58}$

From this letter we can see that issues had arisen yet again regarding the state of the Glasgow botanic garden. In this case, that Lang was finding it necessary to collect plants from elsewhere to satisfy Brown's teaching needs. The garden was in fact in such a poor state that Brown in the same letter despaired, 'I have so little to shew the students, everything looks so meager, that I was even doubtful of the propriety of raising the fee'. ${ }^{59}$ The interrelationship between botanic teaching and the garden can also be seen in the rules for the Oxford professor of botany in the 1730s, which stated, 'the Length of ye Lectures to be calculated in Proportion to ye number of Plants growing in the Garden so as that ye whole Garden may be demonstrated every year'. ${ }^{60}$ Similarly, the Royal Dublin Society stated that at Glasnevin, 'Lectures on Botany at large, to be given during the season when the generality of plants are in flower, for the better demonstration of the sexual system. And the professor [is] to be allowed to use the house and gardens for delivering

Applied in the Arts, Medicine, and in Domestic Economy, vol. 1, London: John Murray, 1830. Shultes states that 'at present the sons carry on the management of this large nursery, which they themselves say contains one hundred acres, and requires the labour of from one hundred and fifty to two hundred workmen' (p. 74). This is obviously a commercial operation on a much larger scale but it suggests that Glasgow was woefully underresourced. Thanks to Suzanne Moss for this reference.

56 Boney, op. cit. (1), p. 227. He succeeded William Hamilton as joint professor of anatomy and botany but seems to have preferred teaching anatomy.

57 Boney, op. cit. (1), p. 277.

58 Boney, op. cit. (1), pp. 243-244.

59 Letter from Dr Brown to Dr Jeffray, Thursday 12 June 1806, Glasgow University Archives, GUA 1961 b.

60 'Botanic Garden Order Book', 7 February 1735, Sherardian Library, MS Sherard 1, p. 5. 
them'. ${ }^{61}$ This direct relationship between teaching material and the course shows how intertwined the physical place and its contents were with the scientific activities, and how crucial the gardeners were as intermediaries and custodians of the living collections.

Brown supported Lang, arguing that 'William has always been active $\&$ intelligent in this part of his duty' as an assistant to the lecturer in botany. ${ }^{62} \mathrm{He}$ went on to make an explicit distinction between common gardeners and those with specialist knowledge, by writing that Jeffray 'must be sensible that a common gardiner, ignorant of the names \& places of growth of the wild plants in this country, would be entirely unqualified for the office of assistant to the Botanical Lectureship on its present foundation'. ${ }^{63}$ This status, assigned by Brown, raised Lang above a mere labourer or unskilled gardener. It is an instance of social mobility that to a lesser degree resonates with Anne Secord's artisan botanists who created botanical societies where they would share expert botanical knowledge as well as local expertise. ${ }^{64}$ Unfortunately, research for this paper has not yet found a link to any societies for any of the gardeners described, but they were likely to be members of informal as well as more formal botanical networks.

Given the financial difficulties encountered by gardeners, the development of specialist botanical knowledge could be valuable in the acquisition of better-remunerated employment. An advertisement from 1783 recommended that the candidate 'thoroughly understands his business, viz, Kitchen garden, with Forcing in all its branches, also Botanic Garden, Pleasure-garden and Nursery'. ${ }^{65}$ As Mark Laird identifies, the aim of John Claudius Loudon's Gardener's Magazine, established in 1826, was 'to "promote as well as to record social and environmental improvements", including the "conduct and conditions of gardeners". ${ }^{66}$ Laird also describes how gardeners were often classed as just above the level of weeder women 'but not much above the level of beasts' in country house estate accounts in terms of financial cost. ${ }^{67}$

The lack of remuneration for gardeners did not go unnoticed by Hope, and on a to-do list written by him in 1783 he placed the issue of the head gardener's wages at number one: 'wages risen, besides perquisites abridged; selling plants; showing garden; originally way too little'. ${ }^{68}$ Here he also indicated the various other roles performed by Williamson, which included the selling of plants in order to subsidize his income. Conducting these sales placed the botanic garden in a much closer relationship with the commercial

61 Proceedings of the Royal Dublin Society (1 December 1796) 33, p. 19, as quoted in Nuala Johnson, 'Labels and planting regimes: regulating trees at Glasnevin Botanic Gardens, Dublin, 1795-1850', Garden History (2007) 35 Supplement: Cultural and Historical Geographies of the Arboretum, pp. 53-70, 68.

62 Letter from Dr Brown to Dr Jeffray, op. cit. (59).

63 Letter from Dr Brown to Dr Jeffray, op. cit. (59).

64 Anne Secord, 'Science in the pub: artisan botanists in early nineteenth-century Lancashire', History of Science (1994) 32(3), pp. 269-315.

65 Morning Herald and Daily Advertiser, 5 December 1783, 17th and 18th Century Burney Collection.

66 Mark Laird, Natural History of English Gardening, New Haven, CT and London: Yale University Press, 2014, p. 352.

67 Laird, op. cit. (66)

68 Sutherland Forsythe and Donna Cole, Discover the Botanic Cottage, Edinburgh: Royal Botanic Garden Edinburgh, 2016, p. 2. 
nursery than is generally understood. ${ }^{69}$ Hope's list also highlights the additional role of the gardener as someone who showed people around the garden. ${ }^{70}$ As head gardeners were struggling financially, it is no surprise to find that gardeners further down the scale could be classed alongside other more menial posts. For example, in 1822 the minutes of the Glasgow faculty record the employment of 'John Walker to be Gardiner, Bellringer and Scavenger'. ${ }^{71}$ This undermines the importance of specialist horticultural expertise in fulfilling a gardening post but does highlight the blurred lines between various roles within a university setting.

In the case of Lang, with the financial burden of his mother and several younger siblings, it was perhaps unsurprising that he succumbed to the temptation of utilizing his specialist knowledge for his own benefit. In his letter to Jeffray, Brown also admitted that 'William unfortunately engaged in the business of an apothecary, but this imprudence is now over \& I know he lost considerably by the speculation that he will not engage in a similar one'. ${ }^{72}$ Boney suggests that Lang may have used the college's plants for this activity, which might go some way to explaining the committee's general displeasure. ${ }^{73}$

There were clear expectations of how a good gardener should behave if we look at the example of Oxford. A list of rules and an oath were drawn up for the gardener in the 1730s, which give a sense of what the managing committee expected 'a good and skillful Gardiner to do'. ${ }^{74}$ These responsibilities fell under three main categories:

1 The garden: he 'shall take care that all things are kept in good Order and Repair, and that nothing is wanting either for the raising Culture or Preservation of ye Plants'.

2 The visitors: 'The Gardiner shall keep ye several Quarters of ye Garden lock'd up and permit no Person whatsoever to go into them unless ye Professor or himself attends on such Person during his Stay there'.

3 The professor: 'during ye Time of his Lectures and take care that none of ye Students or any other Person leave ye Professor, but that they all keep near to him, \& do not straggle about ye Garden at any distance from him, nor break nor crop ye Plants'. ${ }^{75}$

69 An area explored in detail by Sarah Easterby-Smith in Cultivating Commerce: Cultures of Botany in Britain and France, 1760-1815, Cambridge: Cambridge University Press, 2017.

70 The role of the gardener as someone who would communicate knowledge via formal or informal tours deserves further research. In $1776 \mathrm{Mrs}$ Boscawen wrote to Mrs Delany about her visit to Luton Hoo and describes how she 'entertain'd myself highly above an hour; the gardener more civil and agreeable than ever I saw one, the conservatory more delightful'. The Hon. Mrs Boscawen to Mrs Delany, 14 October 1776, in Lady Augusta Llanover (ed.), The Autobiography and Correspondence of Mary Granville, Mrs. Delany: With Interesting Reminiscences of King George the Third and Queen Charlotte, second series, vol. 3, London: Bentley, 1862, pp. 264-265.

71 Minutes of meetings of the faculty 1813-1825, 13 November 1822, Clerk's Press, Glasgow University Archives, GUA 26698.

72 Letter from Dr Brown to Dr Jeffray, op. cit. (59).

73 Boney, op. cit. (1), p. 247.

74 'Botanic Garden Order Book', op. cit. (60), 8 September 1735, pp. 2-3.

75 'Botanic Garden Order Book', op. cit. (60), 8 September 1735, pp. 2-3. 
This note about the custodianship and care of the plants also links the interdependence of the finances and the gardener's role. One of the clauses of the oath requires him to state that he will 'not suffer any Waste or Damage to be made of any kind whatsoever, nor sell nor permit to be sold any Roots, Plants, Flowers, Fruits, Seeds, or Specimens of Plants, nor give away nor exchange any Thing in the Garden without special Leave from the Professor' ${ }^{76}$ This, and the need to show the professor the accounts of money taken for showing visitors around the greenhouses, suggests that the gardener was expected to behave in a fiscally responsible manner and not to profit excessively from his post. ${ }^{77}$

It is clear from Lang's story that there were similar expectations at Glasgow regarding what constituted a good gardener. The use of college plants for private profit, or allowing his care of the garden to suffer due to his duties as an apothecary, would be in direct contravention of his role as a custodian. Brown tried to counter this concern on Lang's behalf by asking the committee to take into account the paltry " "emoluments" derived from the office of college gardiner', which were not sufficient to maintain a man with his family in such a costly city. ${ }^{78}$ All this appears to have fallen on somewhat deaf ears, and on 25 January 1807 Lang himself wrote a detailed representation to the committee, reflecting Brown's argument regarding his own financial and family circumstances.

Lang's representation countered the blame placed upon him for not keeping the college garden in proper order, and demonstrates the conflict that arose between the various roles Lang was meant to perform. The following is a long quotation but, given its importance as a first-hand account from him, it seems important to include his own words at length:

During the summer when the Botanical lectures are going on, the garden allotted for that Department furnishing but a very few specimens for illustrating the Science of Botany, it is required of me to collect elsewhere whatever plants may be necessary for carrying forward the lectures. For which purpose I have to traverse the country round in search of plants: and that, Gentlemen, not on a particular occasion but almost every day of the course. A great part of my time therefore which should be devoted to dressing the Gardens is occupyed in this manner. Because a certain number of different plants, all in flower, must be had for each lecture. And oftentimes after, I have travelled to a wood or waterside two or three miles from Town. I have been disappointed in finding the individual plants wanted - and must again set out to some other quarter to find them. And Gentlemen, as the number of students last year was upwards of thirty, it became necessary for me to provide upwards of thirty specimens of each individual plant demonstrated. And as several hundred Genera and Species were examined last season, the Botany Garden not furnishing near one hundred in perfect condition. A great proportion of my time must be occupied in this manner. ${ }^{79}$

Here we get a detailed insight into the interrelationship between Lang's role in the classroom and the limitations of the garden as a teaching resource. Through necessity the Rousseauean vision of the gentleman botanizing at leisure is transformed here into a difficult, time-consuming and potentially costly act. Sadly for Lang, neither his

76 'Botanic Garden Order Book', op. cit. (60), 8 September 1735, pp. 2-3.

77 'Botanic Garden Order Book', op. cit. (60), 8 September 1735, pp. 2-3.

78 Letter from Dr Brown to Dr Jeffray, op. cit. (59).

79 Letter from Dr Brown to Dr Jeffray, op. cit. (59). 
testimonial, nor that of Brown, appears to have been enough to convince the committee that he was a good gardener and should be retained. By the end of 1807, Brown was no longer employed by the college as a gardener and he disappears from the record thereafter.

\section{'Esteemed for eminent skill in his profession': John Williamson and the Leith Walk garden}

Edinburgh, like Glasgow, already had established physic gardens when John Hope decided to develop a new botanic garden there in the 1760 s. ${ }^{80}$ Having been awarded the joint chair in botany and materia medica at Edinburgh University, and appointed King's Botanist for Scotland and superintendent of the royal garden in 1761, Hope was well placed to lobby for a new, larger botanic garden, and obtained the necessary funds from the Treasury both to combine the earlier collections and to expand its botanical range. ${ }^{81}$ In this regard, he was far more successful than the Glasgow or earlier Cambridge professors, and the Leith Walk garden was established in 1763 for an ever increasing number of medical students and other interested visitors. ${ }^{82}$

As well as creating a much larger, purpose-built botanic garden, with an immense 140foot glasshouse range for exotics, the Leith Walk space included a 'botanic cottage'. ${ }^{83}$ This was used as both a lecture room for teaching botany (on the first floor) and accommodation (on the ground floor) for the head gardener and his family. ${ }^{84}$ Its location on the periphery of the garden, near the entrance gateway, physically highlights the role of the gardener as a warden or gatekeeper of the collection. The head gardener was visible in both the structure and materiality of the garden through his own cottage, which allowed him to monitor the entrance to the garden; 'the wing walls and doors at their side of the house would serve as staff and public entrances to the garden'. ${ }^{85}$

The first head gardener to live in the cottage was John Williamson. He was head gardener for twenty years from 1760, at the establishment of the Leith Walk garden, until his death in 1780 . His personal role within the Leith operation can also be found as a trace in the early physical layout of the garden. Not only was the cottage marked as Mr Williamson's house on the 1777 plan, but one of the plant beds in front of the

80 The first was created in 1670 by Dr Sibbald and Dr Balfour and located adjacent to Holyrood Palace, and the second was founded at Trinity Hospital soon afterwards, in 1676.

81 Having studied botany in Paris under Bernard de Jussieu, Hope appears to have become more interested in botany than other branches of medical education, and in 1768 he managed to pass the materia medica part of his professorship on to another eminent physician, Francis Home. At that point Hope became the first Regius Professor of Botany at the University of Edinburgh. The Leith Walk garden was initially based on the collections he was allowed and funded to move from the earlier physic gardens, at Trinity and Holyrood.

82 According to Noltie, op. cit. (7), p. 84, 'more than 1700 men attended Hope's lectures in Botany (17611786) and Materia Medica (1761-1767)'.

83 Forsythe and Cole, op. cit. (68), p. 2.

84 For more information on the botanic cottage and its recent reconstruction see Forsythe and Cole, op. cit. (68).

85 Forsythe and Cole, op. cit. (68), p. 5. 
glasshouse was also labelled in Williamson's honour. Having a named bed placed Williamson in exulted botanical company. Other beds in this section of the garden were named after prominent botanists, both contemporary and historical, as well as after patrons, including the influential Lord Bute, and others who exchanged botanical specimens within Hope's extensive and powerful network. After Williamson's untimely death in 1780, Hope installed a memorial to him in the garden, which recorded that he was 'esteemed for eminent skill in his profession' (Figure 3). ${ }^{86}$ That, along with the naming of the bed, suggests that Hope respected his horticultural expertise. This type of monument set within a garden was generally only reserved for more elite figures. At Leith Walk the only other memorial which has survived is a stunning urn dedicated to Linnaeus. This memorial is a physical reminder of the interlinking network of the garden, gardener and professor. As Stephen Harris notes in relation to Oxford, the greatest periods of success for the garden were when 'relationships between horticultural and academic staff are strongest'. ${ }^{87}$

At Leith Walk, the purpose-built cottage with lecture theatre on the first floor emphasized the important role of the botanic garden as a teaching space, and the gardener's place within that sphere. As we have seen, Hope's main focus was on the teaching of botanical science rather than the medicinal uses of plants. Notes of Hope's lectures made by one of his students, Francis Buchanan, support this account of the botanical focus of his courses. ${ }^{88}$ At Edinburgh, as well as needing someone to both grow and demonstrate plants for the students, Hope also employed Williamson to conduct experiments to accompany his lectures. In the lecture notes, Hope explained that in the Leith Walk garden 'we are making experiments here, but experiments on trees and plants are very different from those on animals' ${ }^{89}$ These experimental examples formed the core of much of his teaching and Hope referred to them throughout his lectures. This suggests that the gardener showed the actual experiments to the students or, where this was not possible, Hope specially commissioned teaching diagrams depicting the results.

Williamson kept a notebook outlining the experiments he was conducting in the garden and their results, as well as a list of experiments that were physically based in the gardener's house. ${ }^{90}$ From this, we can see that Williamson was acting as an invisible technician in common with other areas of scientific endeavour. ${ }^{91}$ The experiment notebook seems to contain two sets of handwriting, which perhaps indicates the co-production of knowledge between Hope and Williamson and again blurs the division between the head and hand. In line with Shapin's argument of the dual invisibility of technicians both in the past and to historians, it is clear that Williamson's research was appropriated

86 The cause of Williamson's death was related to his second employment as a customs officer. It was while acting in this capacity that he was mortally wounded by a group of armed smugglers.

87 Stephen Harris, Oxford Botanic Garden \& Arboretum: A Brief History, Oxford: Bodleian Library, 2017, p. ix.

88 Francis Buchanan, 'Notes taken from Dr. John Hope's lectures on botany', summer 1780, RBGE Archives.

89 Anon., op. cit. (23), p. 7.

90 'A list of specimens of experiments kept in the gardeners house', Botanical Papers of John Hope MD Professor of Botany and Materia Medica at Edinburgh, National Records of Scotland, GD253/145/7/2.

91 Hope, op. cit. (90); Steven Shapin, 'Invisible technicians', American Scientist (1989) 77(6), pp. 554-563. 


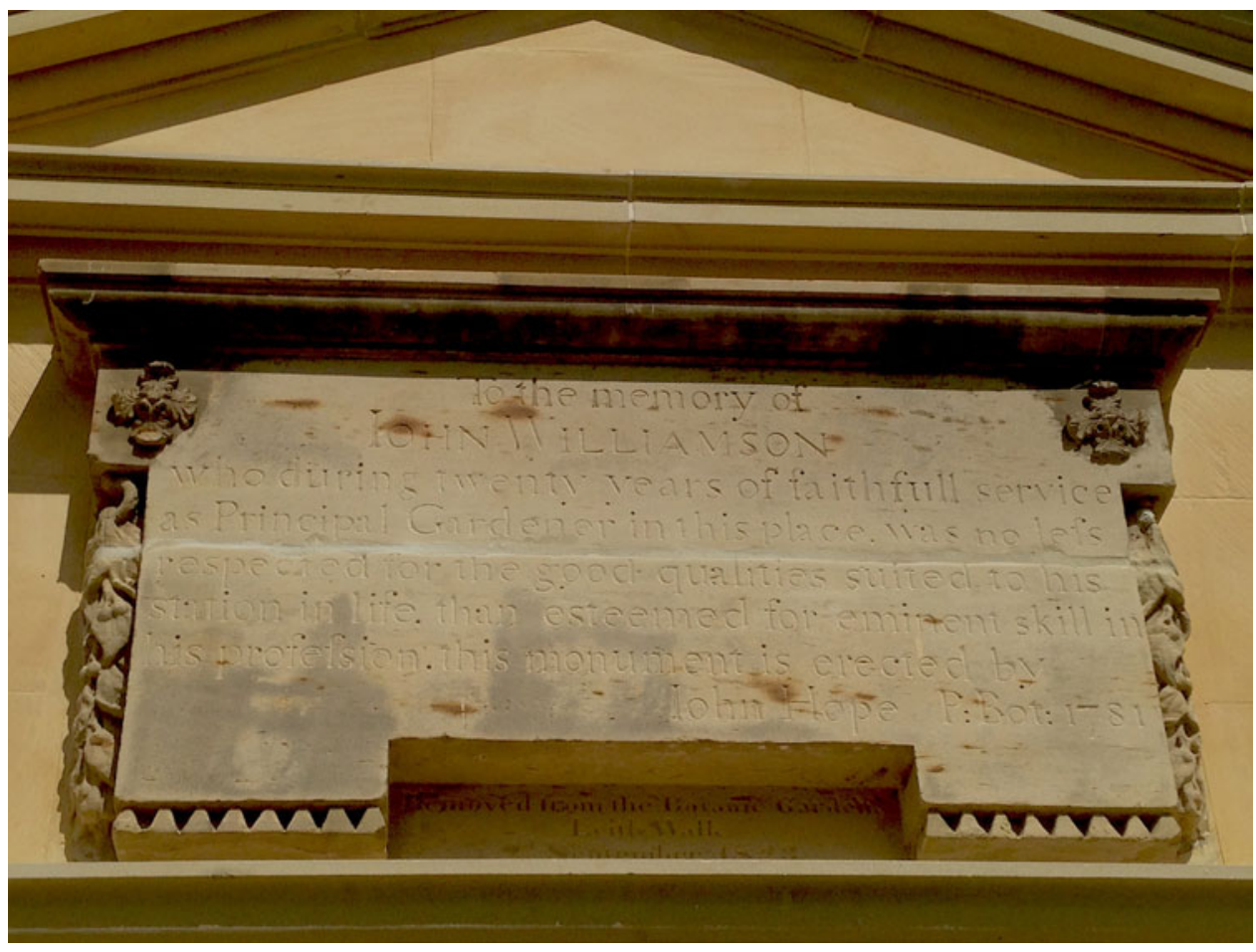

Figure 3. Elegant memorial to John Williamson by Robert Adam in 1779, now in the Royal Botanic Gardens, Edinburgh. Photograph author's own.

by Hope without credit. According to Noltie, Williamson undertook hybridization experiments between the oriental and opium poppies but when Hope reported the experiments to the younger Linnaeus he omitted Williamson's role in the process. ${ }^{92}$ This perhaps indicates that there were limits to the role a skilled technician or gardener could play within the hierarchy of the botanic garden.

Gardeners were an integral part of the teaching process at Edinburgh in other ways that were more befitting of their social status. The fee for the botany course, which was collected by Hope, was two guineas for each of the summer sessions, rising to three guineas in $1770 .{ }^{93}$ According to Jane Corrie, 'these funds were used in part to cover 'payments to the gardeners for assistance with setting up, running and tidying up after the lectures', which establishes the important role gardeners played as facilitators for the delivery of botanical lectures. ${ }^{94}$ Further evidence of the practical roles gardeners played in Hope's classroom can be seen in his own notes. In 1778 he recorded

92 Noltie, op. cit. (7), p. 36.

93 Jane Corrie, 'Botanic Cottage Project report. Stories from the historical archives: about Botanic Cottage, the Leith Walk Garden and John Hope’s “other” life as a physician', May 2009, RBGEl3B Cor.

94 Corrie, op. cit. (93). 
that 'one of the gardeners should keep a register of the students examined' 95 He mentions gardeners holding up specimens of 'waking' plants for students to compare with a drawing of them 'sleeping. ${ }^{96}$ This reflected a widespread interest in plants that moved their leaves at this time and also indicates the use of a variety of pedagogical tools, as well as the role played by drawing as a way of knowing.

Much of Hope's lecture time seems to have been given over to the consideration of plant anatomy and physiology, with references to similar systems in animals and humans. For example, during one lecture a student noted his claim that 'the viscera in animals are circumscribed, but in vegetables they are diffused over the whole system, by this you see they are so much more difficult to be investigated' ${ }^{97}$ This relationship between botanic and anatomical knowledge can further be seen in the use of objectbased learning. Hope's contemporary, the anatomist and man-midwife William Hunter, described how specimens were to be passed out around the room, one student describing to the next what was to be seen. ${ }^{98}$ This sensory approach was embedded in a longer history of knowing objects through sensory practice. ${ }^{99}$ As Sarah Easterby-Smith states, 'learning and practising botany in the eighteenth century involved collecting specimens, identifying them and conserving them (or their representations) for future reference'. ${ }^{100}$ The practice of collecting took various forms, including the gathering of living specimens in gardens, of dried examples in herbaria, and of visual or material representations. As Easterby-Smith notes, the exchange of objects in order to build these collections 'meant that botany and horticulture, like the other descriptive disciplines that comprised natural history, were notably sociable'. ${ }^{101}$ It is perhaps, then, not surprising that gardeners became collectors in their own right as collecting was both an integral part of training the senses and a means of participation within important networks.

Thomas Somerville was a later head gardener at Leith Walk (1807-1810) and his personal collection of books and specimens was sold on his death in April 1810. ${ }^{102}$ Within the sales particulars Sommerville was described as the manager of the Edinburgh botanic garden, but we know little else about him. Notes on the botanic garden compiled at the start of the twentieth century describe him only as having been in the role for three years and just twenty-seven years old when he died. The notice of his death in the Scots Magazine of 1810 described him as a 'young man of great abilities both as a professional

95 John Hope, 'Remarks on lectures', RBGE Archives, GD253/144/14/16.

96 Hope, op. cit. (95).

97 Anon., op. cit. (23), pp. 60-61.

98 From Carin Berkowitz, Charles Bell and the Anatomy of Reform, Chicago: The University of Chicago Press, 2015, p. 48.

99 Constance Classen, 'Museum manners: the sensory life of the early museum', Journal of Social History (2007) 40(4), pp. 895-914.

100 Sarah Easterby-Smith, 'Selling beautiful knowledge: amateurship, botany and the market-place in eighteenth-century France', Journal of Eighteenth-Century Studies (2013) 36(4), pp. 531-543, 532.

101 Easterby-Smith, op. cit. (100), p. 532.

102 'Catalogue of Minerals, Fossils, Books, \&c. which belonged to the late Mr Thos. Somerville, Manager of the Botanic Garden, Edinburgh, to be sold Saturday April 28, 1810 at his house Botanic Garden, Leith Walk', RBGE Archives. 
gardener and botanist', which suggests that his abilities were widely recognized. ${ }^{103}$ The list of his collection within the sales particulars is seven pages long and includes a variety of objects such as minerals, shells, fungus, crabs, a petrified oyster, stuffed birds, a hairball from the stomach of a cow, pressing boards and a book for collecting dried specimens, and various botanical works including 'Boerhaave's Index Plantarum and Linnaeus system of Nature in 7 vols. translated by Turton' ${ }^{104}$ One can only speculate whether this varied collection of specimens and books was used by Somerville for his own private study, to facilitate his own networking, as a financial legacy for his family or for teaching students. Nonetheless, the ownership of such a collection suggests that Somerville was involved in knowledge creation within sociable networks similar to those in which more elite gentlemen such as Hope participated.

There are suggestions that gardeners were also facilitating the creation and dissemination of knowledge within country house estates, which is a topic deserving of further study. For example, we know that at Bulstrode Park in Buckinghamshire, the gardener accompanied the avid naturalist and plant collector the Duchess of Portland and her friends and fellow conchologists on expeditions to gather freshwater snails and bivalves in the local area. ${ }^{105}$ Upon their return to the house, a lively discussion concerning the classification of shells would take place in the presence of 'visiting naturalists, and interested members of her household, including Mary Delany, the Reverend Lightfoot, the artist Ehret, and even her gardener J. Agnew'.106

When Lightfoot wrote up his account of the discovery of new shells for Philosophical Transactions, Agnew and even the duchess (as a woman) were only mentioned in passing. Towards the end of his letter to Joseph Banks, Lightfoot recorded that Patella oblongata 'was found adhering to the leaves of the Iris pseudacorus in waters near Beaconsfield, in Buckinghamshire, by Mr Agnew, Gardener to the late Duchess Dowager of Portland; by whose sagacity wall the preceding shells were discovered, and by whose faithful pencil they were drawn' ${ }^{107}$ Here at least Agnew receives credit for both the discovery and the scientific drawing, whereas the Duchess of Portland is only referred to as his employer. This erasure is similar to that of Hope's accounts of experiments conducted by Williamson and does suggest that the involvement of gardeners in the creation and recording of knowledge has been overlooked to date. The secondary role of some gardeners, like Agnew, as scientific illustrators will be explored below, although it deserves further analysis beyond the confines of this paper.

103 Scots Magazine and Edinburgh Literary Miscellany, Edinburgh: J. Harden \& Co., 1810, p. 318.

104 'Catalogue of Minerals, Fossils, Books, \&c.', op. cit. (102).

105 For more on the Duchess of Portland and her interests in botany see Alexandra Cook, 'Botanical exchanges: Jean-Jacques Rousseau and the Duchess of Portland', History of European Ideas (2007) 33(2), pp. 142-156.

106 Beth Fowkes Tobin, 'Bluestockings and the cultures of natural history', in Deborah Heller (ed.), Bluestockings Now! The Evolution of a Social Role, London: Routledge, 2016, pp. 55-70, 66.

107 John Lightfoot, 'An Account of Some Minute British Shells, Either not Duly Observed, or Totally Unnoticed by Authors in a Letter to Sir Joseph Banks, Bart. P.R.S', Philosophical Transactions of the Royal Society (1786) 76, pp. 160-170, 168. 
'Every figure necessary to be shewn drawn by Andrew Fife': Andrew Fyfe as an intermediary between the botanic and the anatomy classrooms

There were, of course, other gardeners ranked below men such as Lang and Williamson, like Benwell at Oxford, of whom we know even less despite their importance to the botanic network. A recent list compiled by the Royal Botanic Garden Edinburgh records 162 gardeners mentioned by name in the accounts as working at the Leith Walk garden between 1763 and 1810. ${ }^{108}$ Beside them worked numerous labourers whose presence was not recorded. There were also other technicians working in the garden alongside the gardeners, and people who acted as gardeners could also be employed in other capacities. Noltie has identified the most important of Hope's gardener-assistants as Archibald Menzies, John Lindsay, James Robertson and Andrew Fyfe. ${ }^{109}$

In this article, we will interrogate the role of one of these, Andrew Fyfe, chosen because he offers us a direct link between anatomical and botanical teaching in Edinburgh. ${ }^{110}$ Fyfe first appeared in the record as a gardener in the Leith Walk garden between 1772 and 1775 and there was a note mentioning him as collecting plants in a visit with Hope in 1773. ${ }^{111}$ In 1776 the Caledonian Mercury noted that he was awarded a prize for his drawings of flowers and foliage and that he was no longer an assistant gardener but now a student of physic. ${ }^{112}$ In the same year Hope records his decision that 'every figure necessary to be shewn [should be] drawn by Andrew Fife [sic] and of such size that it may be seen at any distance in the room' ${ }^{113}$ This suggests that while Fyfe was a medical student, Hope was promoting his skills as a technical artist as well as employing him to create large botanical drawings as teaching aids for the classroom (Figure 4). Fyfe was not alone in producing drawings for Hope's classroom. As Noltie has identified, the largest category of diagrams produced for Hope was created by his 'gardener-assistants', including John Lindsay and John Bell. A number of diagrams were also produced by Agnes Williamson, John Williamson's daughter and later Fyfe's wife. ${ }^{114}$

Alongside - or at least soon after - his time working for Hope, Fyfe began to be employed in the Anatomy Department of Edinburgh University. The ODNB entry for Fyfe focuses solely on his anatomical role and omits his botanical interests, stating that in 1771 he became 'principal janitor and macer in the university, a post then

108 This list can be downloaded from the RBGE website: www.rbge.org.uk/assets/files/science/Library\%20Archives/LeithWalkGardeners1763_1810.pdf, accessed 30 August 2016.

109 Noltie, op. cit. (7), p. 38.

110 The link between anatomical and botanical practices is generally overlooked when considering Georgian medicine; however, the close relationship of the two subjects in the sixteenth century has been expertly outlined by Sachiko Kusukawa, in Picturing the Book of Nature: Image, Text, and Argument in Sixteenth-Century Human Anatomy and Medical Botany, Chicago: The University of Chicago Press, 2012.

111 Noltie, op. cit. (7), p. 38.

112 Caledonian Mercury, 4 March 1776.

113 Hope, op. cit. (95).

114 Noltie, op. cit. (7), p. 81. 


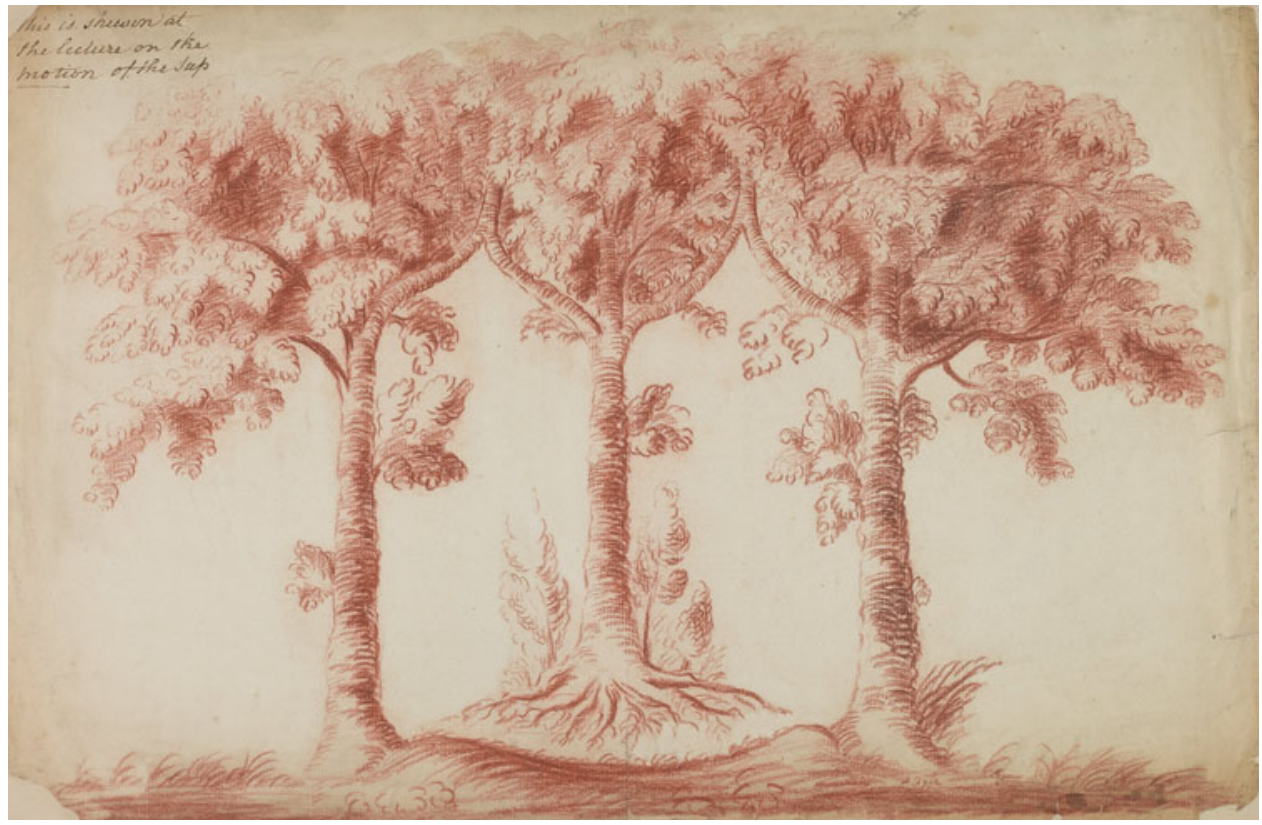

Figure 4. Drawing by Andrew Fyfe, elaborated from Hale's Vegetable Staticks to demonstrate how the willow trees were grafted together at Leith Walk. The soil was dug from beneath the middle tree, which continued to grow due to sap from the outer trees. The note in the corner, probably written by John Hope, records that this is shewn on the lecture of the motion of the sap'. Royal Botanic Garden Edinburgh Archive, D32 ret. Reproduced with permission from the Royal Botanic Garden Edinburgh.

usually held by a student, which provided free living quarters'. ${ }^{115}$ Again this reflects the precariousness of employment in this period. Highlighting his artistic prowess, Fyfe produced a couple of anatomical textbooks that included his own drawings, thereby making him a key figure producing teaching materials for both botany and anatomy in Edinburgh. ${ }^{116}$ Fyfe acted as the curator of a collection of anatomical figures given to the university by Monro Secundus in 1800, which suggests that he was also interested in the material culture of teaching as well as that of illustration. As Daniela Bleichmar observes, illustrations were crucial to naturalists in the eighteenth century as they helped to bridge the gap between 'objects "out there" in the field and the world of

115 Jo Currie, 'Fyfe, Andrew (1752-1824)', Oxford Dictionary of National Biography, Oxford University Press, 2004, at www.oxforddnb.com/view/article/10256, accessed 31 January 2016.

116 For more on his anatomical work see M.H. Kaufman, 'Observations on some of the plates used to illustrate the lymphatics section of Andrew Fyfe's Compendium of the Anatomy of the Human Body, published in 1800', Clinical Anatomy (1999) 12(1), pp. 27-34; Mohammadali M. Shoja, Martin M. Mortazavi, Mehran Malakpour, Marios Loukas, Curtis J. Rozzelle and R. Shane Tubbs, 'Fyfe the Elder (1752(4)-1824): Not all good anatomists are good teachers', Clinical Anatomy (2013) 26(4), pp. 418-422. 
objects “in here" in collections'. ${ }^{117}$ The illustrations created by Fyfe were similar in their ability to link objects in life with the dead specimens of the teaching room. It is perhaps this connection between anatomical and botanical teaching that gives us another way of considering the role of technicians like Lang, Williamson and Fyfe in this period. The relationship between the visual identification needs of both anatomy and botany has already been noted by Noltie; however, there is an argument to be made that the visual is not the only connection between the two disciplines. ${ }^{118}$

Carin Berkowitz's work on the anatomist and artist Charles Bell, who was a contemporary of Fyfe and Lang, provides a useful framework for considering Fyfe's role. Berkowitz analyses the pedagogical use in anatomical study of a variety of three-dimensional models, sculptures and specimens, alongside images in books, paintings and classroom drawings, and actual bodies (both dead and alive). ${ }^{119}$ She describes these media as interrelated tools that functioned together alongside texts 'to serve pedagogical and research functions, endeavours that often coalesced in a science that was rooted in the classroom'. ${ }^{120}$ Clear parallels can be drawn with the use of botanic collections as tools for teaching and the associated illustrations, models and collections (such as herbaria) that were used in conjunction with botanical specimens brought in from the garden or the field. Once viewed from inside the classroom, the gardeners, like the anatomical illustrators outlined by Berkowitz, take on a crucial role in the dissemination and production of knowledge within the botanic garden. Far more than labourers of the soil, they were part of the scientific and educational venture of the institution.

There are indications that there were also teaching resources shared between various disciplines during this period. The Glasgow faculty minutes contain a draft list of regulations for the use of the Hunterian collection (as donated by William Hunter). Within this list the minutes state that 'the Professors \& Lecturers of Anatomy, Botany, Natural History, Midwifery \& Materia Medica shall have access to the Corresponding Departments of the Museum, and the privilege of borrowing from it such preparations specimens and articles as may be necessary and useful in their Public Lectures \& Studies'. ${ }^{121}$ Perhaps, then, we need to consider the way subjects were taught based on the material objects used, and to ask who else, apart from the professor or other lecturing staff, was involved in their creation and use.

Berkowitz also discusses the use of collections of objects in Bell's anatomy classes at the Great Windmill School in the early nineteenth century. She describes the importance of the objects as part of Bell's teaching programme and how his pedagogical approach relied on a 'cultivation of sensory perception and the training of hand and eye'. ${ }^{122}$ As

117 Daniela Bleichmar, Visible Empire: Botanical Expeditions \& Visual Culture in the Hispanic Enlightenment, Chicago: The University of Chicago Press, 2012, p. 9.

118 Noltie, op. cit. (7), p. 80.

119 Carin Berkowitz, 'Systems of display: the making of anatomical knowledge in Enlightenment Britain', BJHS (2012) 46(3), pp. 1-29, 26.

120 Berkowitz, op. cit. (119), p. 26.

121 Minutes of meetings of the faculty 1806-1813, 20 October 1807, Glasgow University Archives 26697, Clerk's Press 82.

122 Berkowitz, op. cit. (98), p. 48. 
we have already seen above, Hope's aim was to encourage a sensory understanding of botany, so the training of hand and eye is perhaps comparable between his own discipline and that of anatomy. The role of Fyfe as a mediator between both the botanical and anatomical classrooms is less surprising once one understands that the pedagogical techniques were closely related. This aspect of learning through drawing, the training of hand and eye, might go some way to explaining the skilled draughtsmanship of both Fyfe and Agnew, as learning through illustration was also part of botanical training. ${ }^{123}$

\section{Conclusion}

What these cases highlight is the complex network of expertise that worked both within and beyond the immediate confines of the botanic garden. Rather than seeing gardeners as a homogeneous mass, we can instead begin to unpick their different roles and biographies and view them as occupying a range of skilled and academic positions. Head gardeners in particular could act as intermediaries between the academic head and horticultural hand, although these roles seem to be more interchangeable than they at first appear. This point is highlighted by the example of William Baxter, custodian of the Oxford Botanic Garden in the nineteenth century, who not only ran the horticultural operation but also gave the botanical lectures under the professorial terms of George Williams and Charles Daubeny. ${ }^{124}$ Here the gardener was expert enough to assume an academic role. However, as we have seen, the flow of expertise was not only in one direction. In the case of Thomas Martyn at Cambridge, the professor could also act as the head gardener when finances were limited. Rather than seeing the head and hand as separate, by close investigation of the different roles of gardeners we can instead see the interlinkages, dependencies and areas of crossover between these superficially highly demarcated posts.

It is also clear that the gardener was often in an economically precarious position and that his fortunes were tied to those of the garden itself. Academic and horticultural actors worked alongside each other most successfully where there was sufficient funding for both the physical space and the workers. Yet even in Edinburgh, which had government funding, there were clearly financial limitations: Williamson, for example, evidently needed more than one job in order to support his family, despite Hope's best efforts. The success of gardeners in achieving the status of a good or 'proper gardiner' relied, then, as much upon their relation to the financial, academic and physical resources of the botanic garden as upon their own particular skills and knowledge. Gardeners should be viewed as integral to the knowledge ecologies in which they worked.

Finally, the knowledge creation of the botanic and anatomical classroom can be seen as more closely related if we focus on their intermediaries and assistants, and consider the pedagogic approaches implemented. Art, science, sensorial education and material culture provided shared methods of both understanding and learning about the living world. Technicians, such as gardeners, were not only essential for the creation of knowledge but also acted as conduits for shared methods of understanding.

123 For more on the role of illustration in eighteenth-century natural history approaches see Bleichmar, op. cit. (117).

124 Harris, op. cit. (87), p. 88. 